\title{
A Triple of Corporate Governance, Social Responsibility and Earnings Management
}

\author{
Quang Linh HUYNH*
}

Received: December 19, 2019 Revised: January 30, 2020 Accepted: February 06, 2020

\begin{abstract}
The research aims to explore the links among corporate governance, corporate social responsibility, and earnings management, considering vital roles of each component in Vietnam. There were 500 questionnaires provided to the targeted enterprises, where there were 150 enterprises in Ho Chi Minh Stock Exchange, 150 enterprises in Hanoi Stock Exchange, and 200 enterprises in the unlisted public company market. Of the distributed questionnaires, only 289 replies offered needed information for analyses. The data derived from these firms was based on their annual or sustainability statements that were retrieved from the websites. This research used a sixyear rolling window to calculate earnings management. To compute that variable, lagged year information was included, so the data from 2011 to 2017 was needed to collect. The empirical results show that corporate governance mechanism is a significant moderation in the positive link between good corporate social responsibility and earnings management. Furthermore, corporate social responsibility and earnings management also play mediating roles in the associations among corporate governance, corporate social responsibility, and earnings management. This project recommends that corporate governance mechanism is an essential driver of the managerial behaviors in social responsibility and ethical accounting practices, which are in turn mediators in the joint research model.
\end{abstract}

Keywords: Ethical Behavior, Corporate Governance, Social Responsibility, Earnings Management

JEL Classification Code: G32; G34; M41

\section{Introduction}

Business operation has tremendous effects on stakeholders, society, and the community; hence, concerns on ethical and socially responsible actions that corporations undertake are increasingly considered (Huynh, 2019). Social and ethical concerns are making firms incorporate managerial tools that take into consideration the execution of firm-related regulations and rules and take good conduct for society, the community and stakeholders (RodriguezFernandez, 2016). Consequently, corporate governance has

\footnotetext{
* First Author and Corresponding Author. Vice Dean, School of Economics and Law, Tra Vinh University, Vietnam [Postal Address: 126 Nguyen Thien Thanh Street, Ward 5, Tra Vinh City, 940000, Vietnam] Tel: +84.943820711

Email: huynhquanglinh@tvu.edu.vn

() Copyright: The Author(s)

This is an Open Access article distributed under the terms of the Creative Commons Attribution NonCommercial License (https://creativecommons.org/licenses/by-nc/4.0/) which permits unrestricted noncommercial use, distribution, and reproduction in any medium, provided the original work is properly cited.
}

been considered to handle firms' social and ethical issues after the falls of numerous big corporations related to the misconduct of managers (Dhu \& Hbp, 2019).

Since the beginning of this millennium, a variety of scandals relating to financial accounting practices, for example the ones of FlowTex in 2000, Parmalat in 2003, AIG in 2004 or the latest ones of Pescanova in 2013, Toshiba in 2015 and 1Malaysia Development Berhad in 2018, have occurred (Dessain, Meier, \& Salas, 2008). This has triggered corporate governance issues affecting several important business decisions (Vijayakumaran \& Vijayakumaran, 2019) and public concerns on socially responsible and ethical behaviors and corporate governance within firms (Huynh, 2019).

A series of blooming economic cycles, followed by the falls of financial markets ended in the first global financial crisis during 2007 and 2008 that was also the most severe financial collapse in corporate governance and governmental rules, which occurred due to the delinquency of corporate governance (Dessain et al., 2008). This reveals the hazards of uncontrolled financial markets, ignored risk 
control and miniature governance. Therefore, corporate governance is developed to overcome the separation between ownership and management, and to balance the benefits among various stakeholders, for instance shareholders, consumers, banks, suppliers, local communities, governments, managers, and employees (Rodriguez-Fernandez, 2016).

According to Nainawat and Meena (2013), corporate governance mechanism is relevant to liability and management of ethical decisions in accounting reporting and socially responsible usage of organizational resources. Providing financial accounting principles facilitate managers to flexibly apply accounting discretion on their reported earnings, those managers normally tend to control their firm reported earnings if huge differences in benefits exist among shareholders and those (Almahrog, Marai, \& Knežević, 2015). Ethical practices in accounting reporting, which have been widely recognized as related to morality, which is right or wrong in human action, might have considerable upshots on organizational operating performance (Kantor \& Weisberg, 2002).

Ethics in accounting are concerned with how to make good and moral choices regarding the preparation, presentation, and discovery of financial information, which is linked with earnings management, which leads to reducing earnings quality. In addition, other studies performed by Stuebs and Sun (2015) and Crifo and Rebérioux (2016) conjecture that the factors of corporate governance are ones of the most important driving forces of socially responsible activities firms undertake that lead to the best possible organizational performance. Whereas corporate governance practices are imperative determinants of both earnings managing and socially responsible activities that firms engage in, both earnings management and social responsibility are mutually interconnected (GrasGil, Manzano, \& Fernández, 2016; Gavana, Gottardo, \& Moisello, 2017; Mahrani \& Soewarno, 2018).

The trilogy of earnings management and socially responsible activities and corporate governance has been documented as driving forces of firm performance or success (Han, Kang, \& Shin, 2016; Mahrani \& Soewarno, 2018; Sheikh, Bhutta, \& Sultan, 2019). A range of research has discussed and studied the interrelations between the management of earnings and corporate governance, between socially responsible actions and corporate governance or between corporate social responsibility and the management of earnings. For example, some projects (Shiri, Vaghfi, Soltani, \& Esmaeli, 2012; Dhu \& Hbp, 2019; Essa, Kabir, \& Nguyen, 2016; Latif, Bhatti, \& Raheman, 2017) emphasize the significant function of corporate governance in ensuring the high-quality reported earnings by reducing agency costs; consequently, through controlling opportunistic actions of agents, will may enhance the reliability and relevancy of accounting information.

In contrast, Nyangweso (2018) analyzed the interference of corporate governance in the causal linkage from the management of earnings to audit report lag. This researcher argued that earnings management affects corporate governance, which is in turn an essential determinant of audit report lag; therefore, the link between earnings management and audit report lag is interfered by corporate governance.

As to the relationship between socially responsible actions and corporate governance, previous research regarded corporate governance as a tool to align between social and economic objectives, the role of which is to create profits for firms' owners (Rodriguez-Fernandez, 2016; Huynh, 2019; Javeed \& Lefen, 2019; Akben-Selcuk, 2019). Corporate governance mechanisms are employed to encourage businesses to engage in socially responsible actions. Consequently, the connection of corporate governance to socially responsible actions has been thoroughly investigated in those studies. In addition, the relationship between corporate social responsibility and the management of earnings has also been quite frequently examined in different prior research projects (Gras-Gil et al., 2016; Chih, Shen, \& Kang, 2008; Yoon, Kim, Lee, 2019; Suteja, Gunardi, \& Mirawati, 2016; Sial, Chunmei, Khan, \& Nguyen, 2018). Some of them tried to evaluate the impact of socially responsible activities on manipulating the earnings in accounting reports (Gras-Gil et al., 2016; Gavana et al., 2017; Chih et al., 2008; Yoon et al., 2019).

The others suggested the management of earnings affects socially responsible actions of the firm (Suteja et al., 2016; Gavana et al., 2017) and recommended the moderation of earnings manipulation in the causal link from socially responsible actions to organizational effectiveness (Sial et al., 2018). The abovementioned studies have considered the relationships among corporate governance mechanism, the management of earnings and socially responsible actions in separate research models. Only a modest attention has been paid to the managerial motivations in the management of earnings and corporate social responsibility (Hoang, Abeysekera, \& Ma, 2019). Especially, there are a few studies that have explored these relationships in conjoint research models (Laksmi \& Kamila, 2018; Mahrani \& Soewarno, 2018; Ehsan, Abbas, \& Nawaz, 2018; Choi, Lee, $\&$ Park, 2013). None of them however has comprehensively examined the role of each component in the trilogy of social responsibilities, earnings management and corporate governance within a combined model.

Vietnam's increasingly economic development has not only attracted foreign direct investment, but it has also gone into a transitional period from state ownership to private ownership of firms. Various types of firms have emerged such as partially state-owned firms or partially foreign- 
owned ones (Hoang et al., 2019). This leads to an excessive need to develop and improve corporate governance practices that can constrain managers towards behaving more ethically and responsibly to society and stakeholders. Furthermore, research on corporate governance and ethical activities to the society and community has yet to be adequately examined in Vietnam, while other developed or developing nations are enjoying quite a lot of research on the subjects (Lien \& Holloway, 2014).

Accordingly, it is extremely necessary to do some research on the management of earnings, socially responsible actions, and corporate governance in the context of Vietnam as a developing economy where there remains a lack of attention to these issues. Hence, this research attempts to study the trilogy of socially responsible actions, the management of earnings and corporate governance with the main purpose to evaluate the roles of each of the trilogy within the link among them and the research is conducted in Vietnam. The main aim of this research is to examine the effects of corporate governance on the management of earnings and socially responsible actions by evaluating the intervenient role of socially responsible actions and the management of earnings in the relationships. It then tries to consider the moderating function of corporate governance.

\section{Theoretical Framework}

Big corporate scandals have recently occurred allegedly due to unethical or irresponsible behaviors of the management that has been driven by poor corporate governance (Huynh, 2019). Different research projects have studied issues relevant to corporate governance, unethical practices in accounting and corporate social responsibility; nevertheless, all of them have yet to systematically evaluate the trilogy of socially responsible activities, the management of earnings and corporate governance in a joint research model. This research tries to construct a joint research model for the three components. The relationships of corporate governance with socially responsible actions and with the management of earnings as well as the mutual link between socially responsible activities and the management of earnings will be discussed. Especially, it then attempts to assess the moderation of corporate governance as well as the mediation of socially responsible behaviors and earnings management within the research model.

\subsection{Corporate Governance on Social Responsibility and Earnings Management}

A mechanism of outstanding corporate governance is extremely necessary to a firm, having need of sound governance that could allow the firm to win stakeholders' confidence and assure equality in interest among them (Mahrani \& Soewarno, 2018). Corporate governance is a managerial term referred to as a mechanism of control consisting of the policies, procedures, practices and regulations (Laksmi \& Kamila, 2018). They are used to properly allocate organizational resources in order to maximize benefits for all stakeholders and society. A good corporate governance practice can offer appropriate managerial tools to link stakeholders together such as directors, supervisors, shareholders and others by highlighting the principles of corporate governance responsibility, independence, fairness, transparency and accountability, which is aimed to restrain opportunistic and self-interest managers from behaving unethically and irresponsibly to stakeholders and society (Ikoh, Nsien, \& Nicholas, 2013). Additionally, all corporate governance, socially responsible actions, and the management of earnings are acknowledged as part of a firm-related continuum of responsibility (Bhimani \& Soonawalla, 2005).

The emergence and extent of corporate governance and socially responsible behavior have been imperative problems for years (Jo \& Harjoto, 2012; Latif et al., 2017). Socially responsible activities are a firm's accountability to its stakeholders and society manifested in apparent and moral behaviors of the management (Mahrani \& Soewarno, 2018). Following Jamali, Safieddine, and Rabbath's (2008) research, Jo and Harjoto (2012) conducted a comprehensive literature review of corporate governance and socially responsible activities of a firm and then hypothesized the causal relationship from corporate governance to socially responsible actions. The empirical results from that research show that good corporate governance positively affects socially responsible activities.

Furthermore, Huynh (2019) asserted that companies with good corporate governance likely act more responsibly to society, which allows the companies to win trust from their stakeholders, so gain the best possible performance. Ehsan et al. (2018) emphasized the role of corporate governance in boosting managers to perform socially responsible activities and argued that there has been statistically recognized evidence that corporate governance serves as a catalyst to promote the obligation of social responsibility among managers through embedding useful practices of management.

In addition, good corporate governance also functions as an effective controlling tool to lessen unethical behaviors in manipulating reported earnings, which is related to earnings management (Ehsan et al., 2018). Earnings management is mentioned in Mahrani and Soewarno (2018) as the behavior of directors in manipulating their reported earnings due to several motivations. Following Uwuigbe, Peter, and 
Oyeniyi's (2014) research, Mahrani and Soewarno (2018) argued that the management of earnings is negatively determined by the corporate governance mechanism. Ehsan et al. (2018) consented that good corporate governance mechanism could help a company be more effective in restricting directors from taking advantages of organizational resources for their self-interest by overseeing the managerial boards, because corporate governance is a supervising system. The purpose of it is to monitor business decisions by directors and to restrain their opportunism. Therefore, corporate governance mechanism is recognized essential in limiting the management of earnings by supervising director's self-interest decisions.

The effectiveness of the directorial board is very much dependent on the independence of the board. According to agency theory, independent directors are more sensitive to agency problems because of the principal's supervision. Consequently, they are quite entirely committed to business operation and are usually making better business decisions, which allow their firm to gain good performance. That supervision could limit ethical behaviors in managing reported earnings. Boards of managers and supervisors are the central components constituting corporate governance. The duality of chief executive officer and the independence of supervisory and managerial boards are quite frequently employed as corporate governance mechanism (Dhu \& Hbp 2019).

Anchored in Xie, Davidson, and DaDalt's (2003) study, Dhu and Hbp (2019) affirmed that the manipulation of disclosed earnings occurs so frequently in developing nations where the study revealed that the higher the proportion of independent supervisors and managers in the managerial boards is, the lower the management of reported earnings is. In addition, Dhu and Hbp (2019) also emphasized that two individuals should share the president of the managerial board and the chief executive officer because there is obviously consideration on power in a firm when an individual takes on both the roles of the chairperson and the chief executive officer. Similarly, the separation between the president and the chief executive officer is suggested to positively affect the quality of reported earnings (Anderson, Gillan, \& Deli, 2003). Based on the aforementioned explanation, the following propositions can be hypothesized:

H1: Good corporate governance can develop socially responsible behaviors.

H2: Good corporate governance can limit unethical behaviors in reported earnings.

\subsection{The Mutual Tie between the Management of Earnings and Socially Responsible Actions}

The management of reported earnings and socially responsible activities are recognized in the managerial knowledge as ethical and socially responsible issues; therefore, a great deal of research has tried to discover if they are interplayed (Almahrog, Ali-Aribi, \& Arun, 2018). Various research has documented the negative link between the management of earnings and social responsibility (Chih et al., 2008; Choi et al., 2013; Gras-Gil et al., 2016) and showed that companies with high social responsibility less probably take part in managing reported earnings. Conversely, other research has evidenced a positive connection between the management of earnings and socially responsible actions (Jo \& Harjoto, 2011; Muttakin, Khan, \& Azim, 2015) and recommended that companies that are highly involved in their managing reported earnings likely use social activities to mask their ethical actions.

Other studies argued that the management of earnings is an important determinant of corporate social responsibility (Choi et al., 2013). Further, Chih et al. (2008) advocated that firms that act responsibly to society often try to sustain long-term interaction with their stakeholders, as a result they likely attempt not to exercise the manipulation of reported earnings that may not only mitigate stakeholders' confidence but also diminish their satisfaction with the firms.

Grounded on stakeholder theory, Gras-Gil et al. (2016) explicated that firms try to focus on social responsibility as a strategy to improve the long-term earnings by acknowledging the essential role of every group of interest and then integrating the understanding into the business strategy. As the shareholders supervise vital assets to the survival of the firm, a director desiring the constant success of the organization should pay more consideration to the requirements of all stakeholders. That standpoint leads to the notion that companies with higher social responsibility prefer cultivating continuing associations with their stakeholders to maximizing the temporary earnings.

Behind stakeholder theory, Orlitzky, Schmidt, and Rynes, (2003) offered the fundamental supposition that corporate social responsibility could serve as a controlling tool resulting in better usage of organizational resources, which then likely improves firm performance. Socially responsible actions are deemed as an ethical responsibility of a firm and high corporate social responsibility is extremely preferred by stakeholders. Firms that engage in activities related to social responsibility are more inclined to ethics and have good behavior in response to stakeholders (Carroll, 1979). That perspective also asserts a firm that exercises social responsibility in the situation of ethical accountability likely restricts unethical behaviors in manipulating reported earnings by managers. Firms willing to engage in corporate social responsibility activities tend to avoid any manipulation of their reported earnings, as the manipulation of reported earnings is considered as irresponsible behavior 
in their duty to offer inexact accounting reports.

However, several prior studies have linked the manipulation of earnings to the theory of agency. They considered the difference between ownership and management in contemporary firms, along with asymmetric issues inside them, generates opportunistic behaviors by the directors who often have different goals from the shareholders, which lead them to pursue self-interest objectives. In these circumstances, the manipulation of earnings is regarded a sort of agency cost since directors just take care of their own benefits by disclosing accounting information that is not reflecting the actual financial condition of the business. Therefore, shareholders may not make best possible investments due to agency costs produced from the management of earnings.

The manipulation of earnings not only influences shareholders, but it also affects other stakeholders who are referred to as a group bearing some risk in consequence of having spent some money or something valuable on a company. Management decisions such as the management of earnings can mislead stakeholders about the actual situation of the firm may affect stakeholders severely in particular and society in general (Zahra, Priem, \& Rasheed, 2005).

Directors are empowered to make business decisions; hence, they likely use their power for their own interests, which may generate enormous losses to the other stakeholders. Executives tend to release the overstated information of accounting to divert the concentration of accounting information users away from their behaviors in managing earnings and their socially responsible actions are employed to secure their job and distract stakeholders' consideration from supervising the manipulation of earnings taken by them (Laksmi \& Kamila, 2018). According to Healy and Wahlen (1999), directors are proactively involved in different activities relevant to social responsibility to deal with the negative outcomes derived from earnings management through attracting the public image and organizational reputation.

Furthermore, grounded on legitimacy theory, companies related to the manipulation of earnings likely engage in socially responsible activities to create the image that organizational behavior is ethical and socially responsible and so to distract stakeholders' attention away from their unethical accounting practices in creating reported earnings (Gavana et al., 2017). In contrast, Choi et al. (2013) highlighted apparent earnings reports will provide useful accounting information to stakeholders, which is more related to the business decision making; therefore giving qualified earnings is directly associated with social responsibility, particularly in the intention to satisfy stakeholders. The management of earnings is also proposed in a few studies to negatively affect socially responsible behaviors by managers (Djuitaningsih \& Marsyah, 2012).

The findings from Darabi and Mahmoodi's (2014) suggested directors should pay more attention to the quality of reported earnings to enhance their engagement in socially responsible activities, because both ethical behaviors in earnings reporting and corporate social responsibility could satisfy the firm's stakeholders. Hoang et al. (2019) emphasized that, when companies disclose their profits that are less managed by the directors, it can consider that companies' profits are disclosed ethically and responsibly. In this regard, companies may follow a continuing effectiveness viewpoint on corporate social responsibility. Nevertheless, in developing economies including Vietnam, it is likely that directors undertake opportunistic behaviors for their self-interest from the extensive economic development there. These can lead to the suggestion on the positive relation of the management of earnings to corporate social responsibility in emerging countries. Overall, it can theorize the following propositions for Vietnam's context:

H3: The management of earnings has a positive and bidirectional link to socially responsible behaviors by firms.

\subsection{The Role of Missing Links}

The fact that research on the management of earnings and socially responsible activities of the management suggests conflicting and mixed findings may be because of missing variables that are unconsidered in the research model of corporate governance, earnings management, and socially responsible activities. In the situation between the management of earnings and socially responsible activities, the missing variable could be corporate governance (Ehsan et al., 2018). The existing management knowledge has acknowledged the significant role of corporate governance in constraining managerial behaviors of earnings manipulation and improving socially responsible activities of the management through establishing an effective mechanism of supervising.

Ehsan et al. (2018) declared that a lot of research suggests the statistical moderation of corporate governance into the mutual linkage between the management of earnings and socially responsible activities, although proof has been humble. Furthermore, Choi et al. (2013) explored the moderating role of corporate governance into the causal linkage from the management of earnings to socially responsible activities of the business. In the circumstances between the mechanism of corporate governance and the management of earnings or between the mechanism of corporate governance and socially responsible activities of the management, the missing links could be corporate social responsibility or earnings management. The mechanism of corporate governance determines the 
management of earnings and socially responsible activities, both of which are mutually correlated. Theoretically, corporate governance could promote corporate social responsibility through ethical behaviors in accounting reporting and lessen earnings management through socially responsible mechanism (Baron \& Kenny, 1986). Grounded on the explanation, the following propositions could be suggested:

H4: Corporate governance can moderate the positive and bidirectional link between the management of earnings and socially responsible activities of the management.

H5: Socially responsible activities of the management can mediate the causal association from corporate governance to the management of earnings.

H6: Earnings management can mediate the causal relationship from corporate governance to socially responsible activities of the management.

\section{Research Methodology}

\subsection{Measurements}

Social responsibility $(\boldsymbol{R})$ : This variable was measured according to annual and sustainable development reports of enterprises. The indices were assessed on four dimensions; namely (1) information related to the environment (R1) that consists of 10 items, (2) information in relation to the product (R2) that encompasses 5 items, (3) information involved in the employment (R3) that is composed of 12 items and (4) information regarding supporting and developing community (R4) that includes 8 items. This measurement was modified from Ta and Bui. (2018). First annual or sustainability reports in 2017 were looked through to discover information relevant to these 35 items. An item was recorded as one if the item was not disclosed, as two if the item was disclosed with general information, without clear details or only with quantitative information, and as three if the item was disclosed with detailed explanation. The extent of social responsibility for each firm was calculated by averaging all the item scores of that firm.

Earnings management (EM): Following Essa et al.'s (2016) research, this research employed two proxies for the variable "Earnings management", one of which is based the modified Jones model suggested by Dechow, Sloan, and Sweeney (1995) and the other is grounded on the performance-matching Jones model stipulated by Kothari, Leone, and Wasley (2005).

Corporate governance (C): Modified from Huynh (2019), this research evaluated corporate governance based on the independence of management, the independence of supervision and the separation between chief executive officer and chairperson. The independence of management (C1) is defined as the percentage of independent directors in the management boards. The independence of supervision (C2) is regarded as the percentage of independent supervisors in the supervisory boards. The separation between chief executive officer and chairperson (C3) is a dummy variable labeled zero if the chief executive officer and chairperson is one person; labeled one otherwise. Controlling variables: To overcome the problem arising from associated missing elements, this research enter several controlling variables that have been acknowledged to influence corporate social responsibility and earnings management by various previous studies (Latif et al., 2017). The variables of capital intensity (CI), size (SI), growth opportunity (GO), liquidity (LI) and leverage (LV) likely affect the dependent variables of corporate social responsibility and earnings management.

\subsection{Data Collection}

The population of this research consisted of publicly listed enterprises in Vietnam's major Stock Exchanges. The population of 420 enterprises in Ho Chi Minh stock exchange, 416 enterprises in Hanoi stock exchange, and 913 enterprises in the unlisted public company market at the end of 2017. Consequently, the total number encompasses 1,749 enterprises. However, banks, creditors and other banking-finance institutes were taken away from the research, because the requirements of disclosure information for them are considerably different from the other kinds of firms (Ta \& Bui, 2018). There were 39, 30 and 22 banking-finance institutes in Ho Chi Minh stock exchange, Hanoi stock exchange and the unlisted public company market respectively; so the final targeted number of enterprises was 1658 firms. There were 500 questionnaires provided to the targeted enterprises, where there were 150 enterprises in Ho Chi Minh stock exchange, 150 enterprises in Hanoi stock exchange, and 200 enterprises in the unlisted public company market. These enterprises were chosen by applying the simple random sampling.

Of the distributed questionnaires, only 289 replies offered needed information for analyses. The data derived from these firms was based on their annual or sustainability statements that were retrieved from the websites for Ho Chi Minh stock exchange, Hanoi stock exchange and the unlisted public company market or from the other relevant websites of www.vietstock.vn, www.cophieu68.vn, www.stockbiz.vn, and www.cafef.vn. Drawing on the technique as Essa et al. (2016) employed to compute the variable of earnings management, this research used a sixyear rolling window to calculate earnings management. To 
compute that variable, lagged year information was included, so the data from 2011 to 2017 was needed to collect.

\subsection{Scale Reliability}

After the data had been collected, the two items of earnings management were computed using the formulas of (1) and (2) as Dechow et al. (1995) recommended. Consequently, there are two items for the variable earnings management, three items for the variable corporate governance and four dimensions for the variable corporate social responsibility. In which, there are 10 items for the dimension 'information related to the environment', 5 items for the dimension 'information in relation to the product', 12 items for the dimension 'information involved in the employment' and 8 items for the dimension 'information regarding supporting and developing community'. As for variables with multiple items, reliability analyses are employed. The variable corporate social responsibility was run with the reliability analyses twice. The results for assessing the reliability of scales are shown in Table 1 .

The practical findings indicate that all the 35 items in the research model gain the correlations from 0.507 to 0.81 , all of which exceed 0.5 , the smallest level as Nunnally (1994) recommended. Furthermore, the Cronbach's $\alpha$ s of the scales in Table 1 range from 0.78 to 0.898 , which are greater than 0.7 , the lowest limit stipulated by Nunnally (1994). The aforementioned numbers demonstrate the internal consistency of the items used in the research model. The scales all gain the measurement reliability; hence, they can be appropriately used for subsequent steps.

\section{Empirical Results}

The procedures to test the causal effects and the moderating roles generate the results in Table 2. The models get the variance inflation factors (VIF) of the independent variables in the research models smaller than two, the acceptable level proposed by Nunnally (1994), indicating no multicollinearity occurs in the analyzed data. Besides, the estimates of Durbin-Watson ranging from 1.877 to 1.914 , which are within the scope from du to (4$\mathrm{du}$ ); hence, the autocorrelation does not exist in the data. The F values of the models vary from 104.574 to 210.192 , the Ps of which all are smaller than $1 \%$, indicating the good fitness of the models to the data.

Model 1 shows that the independence of management, the independence of supervision and the separation between chief executive officer and chairperson significantly and negatively affects managers' unethical behaviors in reported earnings, with Bs of $-0.139,-0.344 \&-0.257$ and Std. Es of
$0.042,0.039 \& 0.043$ respectively at the significance level of $1 \%$; so, the proposition $\mathrm{H} 2$ is statistically supported.

Table 1: Scale consistency

\begin{tabular}{|c|c|c|c|c|}
\hline Scale & Dimension & Correlation & $(\alpha)$ if Dimension deleted & $(\alpha)$ \\
\hline \multirow{10}{*}{ R1 } & R101 & .522 & .885 & \multirow{10}{*}{.889} \\
\hline & R102 & .531 & .885 & \\
\hline & R103 & .531 & .885 & \\
\hline & R104 & .507 & .886 & \\
\hline & R105 & .514 & .886 & \\
\hline & R106 & .748 & .869 & \\
\hline & R107 & .722 & .871 & \\
\hline & R108 & .696 & .873 & \\
\hline & R109 & .733 & .871 & \\
\hline & R110 & .746 & .870 & \\
\hline \multirow{5}{*}{$\mathrm{R} 2$} & R201 & .754 & .861 & \multirow{5}{*}{.890} \\
\hline & R202 & .748 & .862 & \\
\hline & R203 & .719 & .869 & \\
\hline & R204 & .701 & .873 & \\
\hline & R205 & .741 & .864 & \\
\hline \multirow{12}{*}{$\mathrm{R} 3$} & R301 & .590 & .891 & \multirow{12}{*}{.898} \\
\hline & R302 & .630 & .889 & \\
\hline & R303 & .617 & .890 & \\
\hline & R304 & .579 & .892 & \\
\hline & R305 & .587 & .891 & \\
\hline & R306 & .599 & .891 & \\
\hline & R307 & .671 & .887 & \\
\hline & R308 & .659 & .888 & \\
\hline & R309 & .523 & .895 & \\
\hline & R310 & .628 & .889 & \\
\hline & R311 & .696 & .886 & \\
\hline & R312 & .625 & .889 & \\
\hline \multirow{8}{*}{ R4 } & R401 & .733 & .874 & \multirow{8}{*}{.893} \\
\hline & R402 & .717 & .875 & \\
\hline & R403 & .640 & .883 & \\
\hline & R404 & .685 & .878 & \\
\hline & R405 & .637 & .883 & \\
\hline & R406 & .679 & .879 & \\
\hline & R407 & .629 & .883 & \\
\hline & R408 & .665 & .880 & \\
\hline \multirow{4}{*}{$\mathrm{R}$} & $\mathrm{R} 1$ & .704 & .745 & \multirow{4}{*}{.820} \\
\hline & R2 & .694 & .749 & \\
\hline & R3 & .527 & .826 & \\
\hline & $\mathrm{R} 4$ & .655 & .770 & \\
\hline \multirow{3}{*}{$\mathrm{C}$} & $\mathrm{C} 1$ & .672 & .664 & \multirow{3}{*}{.780} \\
\hline & $\mathrm{C} 2$ & .710 & .594 & \\
\hline & $\mathrm{C} 3$ & .561 & .795 & \\
\hline \multirow{2}{*}{ EM } & EM1 & .810 & - & \multirow{2}{*}{.888} \\
\hline & EM2 & .810 & - & \\
\hline
\end{tabular}


Table 2: Hierachical regression

\begin{tabular}{|c|c|c|c|c|c|c|c|c|}
\hline & \multicolumn{2}{|c|}{ E (1) } & \multicolumn{2}{|c|}{ E (2) } & \multicolumn{2}{|c|}{ R (3) } & \multicolumn{2}{|c|}{ R (4) } \\
\hline & B & S.E & B & S.E & B & S.E & B & S.E \\
\hline (C) & $\begin{array}{c}4.819 \\
* * *\end{array}$ & .082 & $\begin{array}{c}4.863 \\
* * *\end{array}$ & .159 & $\begin{array}{l}-1.430 \\
* * *\end{array}$ & .440 & -.749 & .529 \\
\hline SI & $\begin{array}{l}.153 \\
* * *\end{array}$ & .040 & $\begin{array}{l}.148 \\
* * *\end{array}$ & .041 & -.093 & .060 & $\begin{array}{c}-.107 \\
*\end{array}$ & .061 \\
\hline LI & $\begin{array}{l}.068 \\
*\end{array}$ & .038 & $\begin{array}{l}.065 \\
*\end{array}$ & .039 & -.035 & .057 & -.063 & .058 \\
\hline LV & -.057 & .041 & -.054 & .042 & $\begin{array}{l}.337 \\
* * *\end{array}$ & .057 & $\begin{array}{l}.318 \\
* * *\end{array}$ & .057 \\
\hline $\mathrm{CI}$ & $\begin{array}{c}.089 \\
* * *\end{array}$ & .028 & $\begin{array}{c}-.089 \\
* * *\end{array}$ & .028 & -.020 & .042 & -.024 & .042 \\
\hline GO & $\begin{array}{c}-.123 \\
* * * \\
\end{array}$ & .031 & $\begin{array}{c}.124 \\
* * * \\
\end{array}$ & .032 & .071 & .048 & .063 & .048 \\
\hline $\mathrm{C} 1$ & $\begin{array}{l}.139 \\
* * *\end{array}$ & .042 & $\begin{array}{c}-.184 \\
* *\end{array}$ & .083 & $\begin{array}{l}.175 \\
* * *\end{array}$ & .063 & $\begin{array}{c}.189 \\
*\end{array}$ & .111 \\
\hline $\mathrm{C} 2$ & $\begin{array}{c}.344 \\
* * *\end{array}$ & .039 & $\begin{array}{c}-.350 \\
* * *\end{array}$ & .089 & $\begin{array}{l}.236 \\
* * *\end{array}$ & .065 & $\begin{array}{l}.306 \\
* * *\end{array}$ & .080 \\
\hline $\mathrm{C} 3$ & $\begin{array}{c}-.257 \\
* * * \\
* * *\end{array}$ & .043 & $\begin{array}{c}-.220 \\
* * \\
\end{array}$ & .088 & $\begin{array}{l}.619 \\
* * *\end{array}$ & .057 & $\begin{array}{l}.468 \\
* * *\end{array}$ & .114 \\
\hline $\mathrm{R}$ & $\begin{array}{l}.140 \\
* * *\end{array}$ & .040 & $\begin{array}{l}.121 \\
*\end{array}$ & .066 & & & & \\
\hline E & & & & & $\begin{array}{l}.310 \\
* * *\end{array}$ & .088 & $\begin{array}{c}.118 \\
* *\end{array}$ & .053 \\
\hline $\mathrm{C} 1 \mathrm{R}$ & & & $\begin{array}{c}.033 \\
*\end{array}$ & .019 & & & & \\
\hline $\mathrm{C} 2 \mathrm{R}$ & & & $\begin{array}{c}.026 \\
* *\end{array}$ & .011 & & & & \\
\hline C3R & & & $\begin{array}{c}-.013 \\
* * *\end{array}$ & .004 & & & & \\
\hline $\mathrm{C} 1 \mathrm{E}$ & & & & & & & $\begin{array}{c}-.022 \\
*\end{array}$ & .013 \\
\hline $\mathrm{C} 2 \mathrm{E}$ & & & & & & & $\begin{array}{c}-.074 \\
*\end{array}$ & .044 \\
\hline C3E & & & & & & & .111 & .065 \\
\hline $\mathrm{F}$ & \multicolumn{2}{|c|}{210.192} & \multicolumn{2}{|c|}{156.257} & \multicolumn{2}{|c|}{136.719} & \multicolumn{2}{|c|}{104.574} \\
\hline $\mathrm{P}$ & \multicolumn{2}{|c|}{.000} & \multicolumn{2}{|c|}{.000} & \multicolumn{2}{|c|}{.000} & \multicolumn{2}{|c|}{.000} \\
\hline $\begin{array}{l}\text { Durbin- } \\
\text { Watson }\end{array}$ & \multicolumn{2}{|c|}{1.893} & \multicolumn{2}{|c|}{1.888} & \multicolumn{2}{|c|}{1.877} & \multicolumn{2}{|c|}{1.914} \\
\hline
\end{tabular}

As Model 3 shows, the independence of management (C1), the independence of supervision (C2) and the separation between chief executive officer and chairperson (C3) positively affect socially responsible behaviors by companies, with Bs of $0.175,0.236 \& 0.619$ and Std. Es of $0.063,0.065 \& 0.057$ respectively at the significance level of $1 \%$. Therefore, the proposition $\mathrm{H} 1$ is in statistical support. In relation to the bidirectional link between earnings management and corporate social responsibility, Model 1 indicates that socially responsible behaviors by companies boost up their management of earnings, with B of 0.140 and Std. Es of 0.040 at the significance level of $1 \%$. These findings are in statistical support of the proposition $\mathrm{H} 3$ that socially responsible behaviors by companies positively affect earnings management. Furthermore, Model 3 demonstrates a positive and significant effect of earnings management on socially responsible behaviors by companies, with B of 0.310 and Std. Es of 0.088 at the significance level of $1 \%$, providing statistical evidence to support the opposite direction of the proposition $\mathrm{H} 3$ that unethical behaviors in managing earnings enable managers to follow socially responsible activities.

The moderating effects of corporate governance were investigated using Models 1, 2, 3 and 4. Including the interactive terms between independent variables and moderating variables into Model 1 and 3 develops Models 2 and 4. As Model 2 exhibits, the interactive elements are all statistically significant, demonstrating the moderators have impact on the causal links, in support for the proposition H4.

Table 3: Regressions for mediating roles

\begin{tabular}{|c|c|c|c|c|c|c|c|c|}
\hline & \multicolumn{2}{|c|}{$R(5)$} & \multicolumn{2}{|c|}{ E (6) } & \multicolumn{2}{|c|}{$\mathbf{R}(7)$} & \multicolumn{2}{|c|}{ E (8) } \\
\hline & B & S.E & B & S.E & B & S.E & B & S.E \\
\hline (C) & .066 & .125 & $\begin{array}{c}4.828 \\
* * *\end{array}$ & .084 & $\begin{array}{c}-1.430 \\
* * *\end{array}$ & .440 & $\begin{array}{l}4.819 \\
* * *\end{array}$ & .082 \\
\hline SI & $-.147 * *$ & .060 & $-.174 * * *$ & .040 & -.093 & .060 & $\begin{array}{l}-.153 \\
* * *\end{array}$ & .040 \\
\hline LI & -.015 & .058 & $\begin{array}{c}.066 \\
*\end{array}$ & .039 & -.035 & .057 & $\begin{array}{c}.068 \\
*\end{array}$ & .038 \\
\hline LV & $\begin{array}{l}.333 \\
* * *\end{array}$ & .058 & -.010 & .039 & $\begin{array}{l}.337 \\
* * *\end{array}$ & .057 & -.057 & .041 \\
\hline $\mathrm{CI}$ & -.050 & .042 & $\begin{array}{l}-.096 \\
* * *\end{array}$ & .028 & -.020 & .042 & $\begin{array}{l}-.089 \\
* * *\end{array}$ & .028 \\
\hline GO & .035 & .048 & $\begin{array}{l}-.118 \\
* * *\end{array}$ & .032 & .071 & .048 & $\begin{array}{l}-.123 \\
* * *\end{array}$ & .031 \\
\hline $\mathrm{C} 1$ & $\begin{array}{l}.138 \\
* *\end{array}$ & .060 & $\begin{array}{l}-.119 \\
* * *\end{array}$ & .043 & $\begin{array}{l}.175 \\
* * *\end{array}$ & .063 & $\begin{array}{l}-.139 \\
* * *\end{array}$ & .042 \\
\hline $\mathrm{C} 2$ & $\begin{array}{l}.135 \\
* *\end{array}$ & .059 & $\begin{array}{l}-.325 \\
* * *\end{array}$ & .040 & $\begin{array}{l}.236 \\
* * *\end{array}$ & .065 & $\begin{array}{l}-.344 \\
* * *\end{array}$ & .039 \\
\hline $\mathrm{C} 3$ & $\begin{array}{l}.564 \\
* * *\end{array}$ & .056 & $\begin{array}{l}-.177 \\
* * *\end{array}$ & .038 & $\begin{array}{l}.619 \\
* * *\end{array}$ & .057 & $\begin{array}{c}-.257 \\
* *\end{array}$ & .043 \\
\hline $\mathrm{R}$ & & & & & & & $\begin{array}{l}.140 \\
* *\end{array}$ & .040 \\
\hline $\mathrm{E}$ & & & & & $\begin{array}{l}.310 \\
* * *\end{array}$ & .088 & & \\
\hline $\mathrm{F}$ & 146. & & 225.5 & & 136 & & 210 & 92 \\
\hline $\mathrm{P}$ & .00 & & .00 & & & & & \\
\hline $\begin{array}{l}\text { Durbin- } \\
\text { Watson }\end{array}$ & 1.9 & & 1.86 & & & & & \\
\hline
\end{tabular}

The inclusion of the independence of management, the independence of supervision, and the separation between chief executive officer and chairperson in Model 1 with earnings management as a dependent variable will influence the effect of corporate social responsibility on earnings management. At the higher levels of the independence of management or the independence of supervision, the influence of corporate social responsibility on earnings management becomes more positive (see the interactions of 0.033 and 0.026 ); while at the higher level of 
the separation between chief executive officer and chairperson, the influence becomes more negative (due to the interaction of -0.013 ).

Conversely, the addition of the independence of management, the independence of supervision and the separation between chief executive officer and chairperson in Model 2 with corporate social responsibility as a dependent variable will affect the influence of earnings management on corporate social responsibility. At the higher levels of the independence of management or the independence of supervision, the influence of corporate social responsibility on earnings management becomes more negative (see the interactions of -0.022 and -0.074 ); whereas while at the higher level of the separation between chief executive officer and chairperson, the impact becomes more positive (the interaction of 0.111 ).

The outcomes from the test of the mediating roles are displayed in Table 3. The numbers illustrate that the Fs of the four models achieve the values from 136.719 to 225.506, the Ps of which are significant at the $1 \%$ level. Additionally, the variance inflation factors (VIF) of the independent variables in these four models do not exceed the two limit recommended by Nunnally (1994), showing no multicollinearity in the models. Furthermore, the coefficients of Durbin-Watson ranging from 1.877 to 1.943 , which are in the range from du to $(4-\mathrm{du})$; hence, there is no autocorrelation in the analyzed data. These abovementioned discussions point out that the models get good fitness to the data.

Table 4: Mediating assessment

\begin{tabular}{|c|c|c|c|}
\hline Mediator & IV-DV link & $\mathbf{t}_{\text {-mediation }}$ & $\mathbf{P}$ \\
\hline \multirow{4}{*}{$\mathrm{R}$} & $\mathrm{C} 1$ on $\mathrm{E}$ & 1.979 & .048 \\
\cline { 2 - 4 } & $\mathrm{C} 2$ on $\mathrm{E}$ & 1.972 & .049 \\
\cline { 2 - 4 } & $\mathrm{C} 3$ on $\mathrm{E}$ & 3.321 & .000 \\
\hline \multirow{4}{*}{$\mathrm{E}$} & $\mathrm{C} 1$ on $\mathrm{R}$ & -2.233 & .026 \\
\cline { 2 - 4 } & $\mathrm{C} 2$ on $\mathrm{R}$ & -3.253 & .001 \\
\cline { 2 - 4 } & $\mathrm{C} 3$ on $\mathrm{R}$ & -2.852 & .004 \\
\hline
\end{tabular}

The three dimensions $\mathrm{C} 1, \mathrm{C} 2$ and $\mathrm{C} 3$ of the variable corporate governance affect socially responsible activities of the management with the influential powers of 0.138 , 0.135 and 0.564 at the significance values of $5 \%, 5 \%$ and $1 \%$ respectively in Model 5. However, the inclusion of the variable earnings management in the model makes the effects more positive up to of $0.175,0.236$, and 0.619 at the $1 \%$ significance level (see Model 7). In addition, earnings management positively influences corporate social responsibility at the $1 \%$ significance level with the 0.310 estimate. In the other regard, the three dimensions of corporate governance affect the management of earnings with the influential powers of $-0.119,-0.325$ and -0.177 at the significance value of $1 \%$ in Model 6 . Nonetheless, the insertion of the variable social responsibility in the model makes the effects more negative down to of $-0.139,-0.344$ and -0.257 at the significance levels of $1 \%, 1 \%$ and $5 \%$ respectively (see Model 8). In addition, social responsibility imposes a positive impact on the management of earnings at the 5\% significance level with the 0.140 estimate. These findings suggest the mediating roles of social responsibility and the management of earnings in the research model.

To test the statistical significance for the mediating effects, this research applied the procedures recommended by Goodman (1960). The results are shown in Table 4 . The figures reveal that socially responsible activities of the management play mediating roles in the causal relationships from the three dimensions of corporate governance $(\mathrm{C} 1, \mathrm{C} 2$ and $\mathrm{C} 3)$ to earnings management at the significance levels of $5 \%, 5 \%$ and $1 \%$ with the mediation of $1.979,1.972$ and 3.321 respectively. These aforementioned findings are in statistical support for the proposition $\mathrm{H} 5$ "Socially responsible activities of the management can mediate the causal association from corporate governance to the management of earnings". Likewise, Table 4 discovers that earnings management statistically mediates the causal links from the three dimensions of corporate governance $(\mathrm{C} 1, \mathrm{C} 2$ and $\mathrm{C} 3)$ to social responsibility at the significance levels of $5 \%, 1 \%$ and $1 \%$ with the mediation of $-2.233,-3.253$ and -2.852 respectively. These previously mentioned findings statistically support the proposition H6.

\section{Conclusions}

The aim of this research is to systematically study the trilogy of earnings management and socially responsible activities and corporate governance, examining the moderation of corporate governance and the mediating roles of earnings management and corporate social responsibility. Corporate governance has been conformed as a fundamental determinant of corporate managerial behaviors relevant to earnings management and corporate social responsibility of the management (Ehsan et al., 2018; Jo \& Harjoto, 2012). Previous studies have demonstrated mixed evidence on the relationship between earnings management and corporate social responsibility of the management. Some of them have showed a negative link; while others have indicated a positive result (Choi et al., 2013).

Nonetheless, a few scholars have stressed that in developing economies including Vietnam, it is likely that directors undertake opportunistic behaviors for their selfinterest; so the association between earnings management and corporate social responsibility should be positive (Hoang, Abeysekera, \& Ma, 2019). Additionally, it is 
essential to include omitted factors into the joint models, so that the results could be more faithful and reliable (Latif et al., 2017). This research investigates the effect of corporate governance on the bidirectional linkage between corporate social responsibility and earnings management. Especially, it takes into consideration the moderating role of corporate governance and the mediating roles of corporate social responsibility and earnings management in the joint research model.

The findings contribute to the extant literature on management in some ways. Firstly, it indicates that corporate governance serves as a good controlling mechanism to diminish unethical behaviors by managers in manipulating reported earnings and to enhance social responsible actions by companies. Secondly, the empirical results reveal that in a developing nation like Vietnam the mutual relationship between social responsible actions by companies and unethical behaviors by managers in manipulating reported earnings exist positive, implying that managers in developing countries likely undertake opportunistic behaviors for their self-interest at the losses of the other stakeholders. Thirdly, this research shows that the independence of management and the independence of supervision function as positive moderators in the causal link from corporate social responsibility to earnings management, but as negative moderators in the causal association from earnings management to corporate social responsibility; whereas the separation between chief executive officer and chairperson plays the opposite roles of moderation. Fourthly, the empirical findings demonstrate that earnings management plays a mediating role in positively enhancing the effects of the three dimensions of corporate governance on corporate social responsibility; whereas corporate social responsibility serves as a mediator in negatively boosting up the impact of the three dimensions of corporate governance on earnings management.

This research is expected to provide stakeholders as well as managerial researchers a higher understanding of the trilogy among corporate governance, earnings management, and corporate social responsibility. They had better take into account special roles of every factor in the research model to the others, so that the analytic results could be more faithful and reliable. The stakeholders in developing economies should pay more attention to socially responsible behaviors of managers and consider whether the managers employ social responsibility to mask their unethical behaviors in managing financial reports for their own benefits. If so, they try to enable the immoral managers to behave more ethically and responsibly to the community and society, so that their companies can enjoy more sustainable growth.

\section{References}

Akben-Selcuk, E. (2019). Corporate Social Responsibility and Financial Performance: The Moderating Role of Ownership Concentration in Turkey. Sustainability, 11(13), 1-10.

Almahrog, Y., Ali-Aribi, Z., \& Arun, T. (2018). Earnings management and corporate social responsibility: UK evidence. Journal of Financial Reporting and Accounting, 16(2), 311332.

Almahrog, Y., Marai, A., \& Knežević, G. (2015). Earnings management and its relations with corporate social responsibility. Facta Universitatis, Series: Economics and Organization, 12(4), 347-356.

Anderson, K. L., Gillan, S., \& Deli, D. (2003). Boards of directors, audit committees, and the information content of earnings. Weinberg Center for Corporate Governance (Working Paper No. 2003-04). http://dx.doi.org/10.2139/ssrn.444241.

Baron, R. M., \& Kenny, D. A. (1986). The moderator-mediator variable distinction in social psychological research: conceptual, strategic, and statistical considerations. Journal of Personality and Social Psychology, 51(6), 1173-1182.

Bhimani, A., \& Soonawalla, K. (2005). From conformance to performance: The corporate responsibilities continuum. Journal of Accounting and Public Policy, 24(3), 165-174.

Carroll, A. B. (1979). A three-dimensional conceptual model of corporate performance. Academy of Management Review, 4(4), 497-505.

Chih, H. L., Shen, C. H., \& Kang, F. C. (2008). Corporate social responsibility, investor protection, and earnings management: Some international evidence. Journal of Business Ethics, 79(12), 179-198.

Choi, B. B., Lee, D., \& Park, Y. (2013). Corporate Social Responsibility, Corporate Governance and Earnings Quality: Evidence from Korea. Corporate Governance: An International Review, 21(5), 447-467.

Crifo, P., \& Rebérioux, A. (2016). Corporate governance and corporate social responsibility: A typology of OECD countries. Journal of Governance and Regulation, 5(2), 14-27.

Darabi, S. N. M., \& Mahmoodi, M. (2014). The Relationship between Earnings Quality and Corporate Social Responsibility Disclosure in Tehran Stock Exchange. International Research Journal of Management Sciences, 2(11), 326-329.

Dechow, P. M., Sloan, R. G., \& Sweeney, A. P. (1995). Detecting earnings management. The Accounting Review, 70(2), 193-225.

Dessain, V., Meier, O., \& Salas, V. (2008). Corporate governance and ethics: Shareholder reality, social responsibility or institutional necessity?M@n@gement, 11(2),65-79.

Djuitaningsih, T., \& Marsyah, W. A. (2012). The influence of earnings management and corporate governance mechanism towards corporate social responsibility disclosure. Media Riset Akuntansi, 2(2), 187-211.

Dhu, H., \& Hbp, C. (2019). Corporate Governance and Earnings Management: A Review. IRE Journals, 2(12), 212-214.

Ehsan, S., Abbas, Q., \& Nawaz, A. (2018). An inquiry into the Relationship between Earnings' Management, Corporate Social Responsibility and Corporate Governance. Abasyn Journal of Social Sciences, 11(1), 104-116.

Essa, S. A. G., Kabir, M. R., \& Nguyen, H. T. (2016). Does 
Corporate Governance Affect Earnings Management? Evidence from Vietnam? In 2016 Vietnam Symposium in Banking and Finance, November 17-18, 2016, Hanoi, Vietnam. Retrieved from https://ris.utwente.nl/ws/portalfiles/portal/15561519/Essa+Kab ir+Nguyen.pdf

Gavana, G., Gottardo, P., \& Moisello, A. M. (2017). Earnings Management and CSR Disclosure, Family vs. Non-Family Firms. Sustainability, 9(12), 1-21.

Goodman, L. A. (1960). On the exact variance of products. Journal of the American Statistical Association, 55(292), 708713.

Gras-Gil, E., Manzano, M. P., \& Fernández, J. H. (2016). Investigating the relationship between corporate social responsibility and earnings management: Evidence from Spain. BRQ Business Research Quarterly, 19(4), 289-299.

Han, S.-H., Kang, K., \& Shin, Y. S. (2016). Bond ratings, corporate governance, and cost of debt: The case of Korea. Journal of Asian Finance, Economics and Business, 3(3), 5-15. https://doi.org/10.13106/jafeb.2016.vol3.no3.5.

Healy, P. M., \& Wahlen, J. M. (1999). A review of the earnings management literature and its implications for standard setting. Accounting Horizons, 13(4), 365-383.

Hoang, T. C., Abeysekera, I., \& Ma, S. (2019). Earnings Quality and Corporate Social Disclosure: The Moderating Role of State and Foreign Ownership in Vietnamese Listed Firms. Emerging Markets Finance and Trade, 55(2), 272-288.

Huynh, Q. L. (2019). Intervention of Corporate Social Responsibility between Financial Effectiveness and Corporate Governance. Indian Journal of Science and Technology, 12(13), 1-9.

Ikoh, I. M., Nsien, C. B., \& Nicholas, W. T. I. (2013). Corporate governance and banks' turmoils: Assessment of shareholders response. Journal of Educational and Social Research, 3(8), $39-47$.

Jamali, D., Safieddine, A., \& Rabbath, M. (2008). Corporate governance and corporate social responsibility synergies and interrelationships. Corporate Governance: An International Review, 16(5), 443-459.

Javeed, S., \& Lefen, L. (2019). An analysis of corporate social responsibility and firm performance with moderating effects of CEO power and ownership structure: A case study of the manufacturing sector of Pakistan. Sustainability, 11(1), 1-25.

Jo, H., \& Harjoto, M. A. (2012). The causal effect of corporate governance on corporate social responsibility. Journal of Business Ethics, 106(1), 53-72.

Kantor, J., \& Weisberg, J. (2002). Ethical attitudes and ethical behavior: are managers role-models? International Journal of Manpower, 23(8), 687-703.

Kothari, S. P., Leone, A. J., \& Wasley, C. E. (2005). Performance matched discretionary accrual measures. Journal of Accounting and Economics, 39(1), 163-197.

Laksmi, A. C., \& Kamila, Z. (2018). The effect of good corporate governance and earnings management to corporate social responsibility disclosure. Academy of Accounting and Financial Studies Journal, 22(1), 1-16.

Latif, K., Bhatti, A. A., \& Raheman, A. (2017). Earnings quality: A missing link between corporate governance and firm value. Business \& Economic Review, 9(2), 255-280.
Lien, T. T. H., \& Holloway, D. A. (2014). Developments in corporate governance: The case of Vietnam. Corporate Ownership \& Control, 11(3), 219-230.

Mahrani, M., \& Soewarno, N. (2018). The effect of good corporate governance mechanism and corporate social responsibility on financial performance with earnings management as mediating variable. Asian Journal of Accounting Research, 3(1), 41-60.

Muttakin, M. B., Khan, A., \& Azim, M. I. (2015). Corporate social responsibility disclosures and earnings quality: Are they a reflection of managers' opportunistic behavior? Managerial Auditing Journal, 30(3), 277-298.

Nainawat, R., \& Meena, R. (2013). Corporate governance and business ethics. Global Journal of Management and Business Studies, 3(10), 1085-1090.

Nunnally, J. C. (1994). Psychometric theory. New York, NY: McGraw-Hill Education.

Nyangweso, M. A. (2017). The Mediating effect of corporate governance quality on the association between audit report lag and earnings quality in NSE [Doctoral dissertation, Strathmore University].

Orlitzky, M., Schmidt, F. L., \& Rynes, S. L. (2003). Corporate social and financial performance: A meta-analysis. Organization Studies, 24(3), 403-441.

Rodriguez-Fernandez, M. (2016). Social responsibility and financial performance: The role of good corporate governance. BRQ Business Research Quarterly, 19(2), 137-151.

Sheikh, M. F., Bhutta, A. I., \& Sultan, J. (2019). CEO Compensation and Unobserved Firm Performance in Pakistan. Journal of Asian Finance, Economics and Business, 6(3), 305313. https://doi.org/10.13106/jafeb.2019.vol6.no3.305

Shiri, M. M., Vaghfi, S. H., Soltani, J., \& Esmaeli, M. (2012). Corporate governance and earning quality: Evidence from Iran. Middle-East Journal of Scientific Research, 11(6), 702-708.

Sial, M. S., Chunmei, Z., Khan, T., \& Nguyen, V. K. (2018). Corporate social responsibility, firm performance and the moderating effect of earnings management in Chinese firms. Asia-Pacific Journal of Business Administration, 10(2/3), 184199.

Stuebs, M., \& Sun, L. (2015). Corporate governance and social responsibility. International Journal of Law and Management, 57(1), 38-52.

Suteja, J., Gunardi, A., \& Mirawati, A. (2016). Moderating effect of earnings management on the relationship between corporate social responsibility disclosure and profitability of banks in Indonesia. International Journal of Economics and Financial Issues, 6(4), 1360-1365.

Ta, H. T., \& Bui, N. T. (2018). Effect of Corporate Social Responsibility Disclosure on Financial Performance. Asian Journal of Finance \& Accounting, 10(1), 40-58.

Uwuigbe, U., Peter, D. S., \& Oyeniyi, A. (2014). The effects of corporate governance mechanisms on earnings management of listed firms in Nigeria. Accounting and Management Information Systems, 13(1), 159-174.

Vijayakumaran, S., \& Vijayakumaran, R. (2019). Corporate governance and capital structure decisions: Evidence from Chinese listed companies. Journal of Asian Finance, $\begin{array}{lll}\text { Economics and } \text { Business, 6(3), } & \text { 67-79. }\end{array}$ https://doi.org/10.13106/jafeb.2019.vol6.no3.67 
Xie, B., Davidson, W. N., \& DaDalt, P. J. (2003). Earnings management and corporate governance: The role of the board and the audit committee. Journal of Corporate Finance, 9(3), 295-316.

Yoon, B., Kim, B., \& Lee, J. H. (2019). Is Earnings Quality Associated with Corporate Social Responsibility? Evidence from the Korean Market. Sustainability, 11(15), 1-20. https://doi.org/10.3390/su11154116.

Zahra, S. A., Priem, R. L., \& Rasheed, A. A. (2005). The antecedents and consequences of top management fraud. Journal of Management, 31(6), 803-328. 